\title{
Acacia blayana, a new species from the South Coast of New South Wales (Acacia sect. Botrycephalae: Fabaceae)
}

\author{
Mary D. Tindale and A.B. Court
}

\begin{abstract}
Tindale, ${ }^{1}$ Mary D., and Court, ${ }^{2}$ A.B. $\left({ }^{1}\right.$ Royal Botanic Gardens, Sydney, N.S.W. 2000; ${ }^{2} 71$ Miller Street, O'Connor, A.C.T. 2601, formerly Australian National Botanic Gardens, Canberra City, A.C.T. 2601) 1990. Acacia blayana, a new species from the South Coast of New South Wales (Acacia sect. Botrycephalae: Fabaceae). Telopea 4(1): 109-113. A new bipinnate species of Acacia from southeastern New South Wales, Australia, is described and illustrated. Its putative relationships are presented. A key is provided to A. blayana Tind. \& Court and allied species.
\end{abstract}

\section{Introduction}

A new species of Acacia is described, prior to the forthcoming volume 2 of the Flora of New South Wales.

\section{Taxonomy}

The terminology of shapes in the specific description is that defined by Lee (1948: 144).

Acacia blayana Tind. et Court, sp. nov.

Acacia blayana affinis A. pruinosae Cunn. ex Benth. a qua differt habitu arborescenti (arbor usque ad $25 \mathrm{~m}$ ), ramulis angularibus, pinnulis pubescentibus, $10-30 \mathrm{~mm}$ longis, calycibus $0.8-1.3 \mathrm{~mm}$ longis, corollis $1.8-2.0 \mathrm{~mm}$ longis, seminum pleurogrammate late aperto; affinis $A$. schinoides Benth. a qua differt pinnulis puberulis et glande orbiculari singula basi pinnarum parum omnium.

HolotyPus: NEW SOUTH WALES: Brogo River Catchment, Galoon Creek, $22.5 \mathrm{~km}$ WSW of Cobargo, $36^{\circ} 27^{\prime} \mathrm{S}, 149^{\circ} 39^{\prime} \mathrm{E}$, gully, pure stand in Eucalyptus forest, tree to $25 \mathrm{~m}, \mathrm{~J}$. Blay CBG 8213173, ix.1982 (NSW). Isotypi: CBG, K, MEL, PERTH, USDA.

Tree to $25 \mathrm{~m}$ high, d.b.h. to $36 \mathrm{~cm}$; crown small and open; bark dark grey. Branchlets green, brown or purplish, mostly glaucous, angular towards their apices, glabrous or almost so except towards their apices, puberulous with appressed white hairs 0.1-0.2 $\mathrm{mm}$ long, lenticels not prominent. New leaves at tip of branchlets whitish. Leaves bipinnate, glaucous, $17-18 \mathrm{~cm}$ long, $8-10 \mathrm{~cm}$ wide; pulvinus basal, glabrous or \pm puberulous, green or dark brown, $2-5 \mathrm{~mm}$ long; petiole $2.0-5.5 \mathrm{~cm}$ long, ridged, slightly flattened vertically, sparsely puberulous towards the apex; rhachis $1.5-6.0 \mathrm{~cm}$ long, ridged, \pm flattened vertically, with a central trough, \pm puberulous, bearing orbicular, greyish brown to dark brown, \pm puberulous or glabrous glands $0.8-1.2 \mathrm{~mm}$ long each with a cream-coloured orifice, at the base of each pair of pinnae, the gland near the lowest pair often slightly elongated and rarely to $6 \mathrm{~mm}$ below the latter pair on the petiole; terminal seta \pm oblong or deltate, $0.6-0.8 \mathrm{~mm}$ long, straight or curved, bearing a minute orbicular gland; pinnae (2-)3-4 pairs, $4.0-9.5 \mathrm{~cm}$ long, $2.0-3.6 \mathrm{~cm}$ wide; 
pinnules (7-)12-13 pairs, (1-)1.5-3.0 $\mathrm{cm}$ long, (1.5-) 3-4 mm wide, very narrowly elliptical-oblong, the proximal margin more curved than the distal, clothed on both surfaces with white, \pm appressed, straight or curved hairs $0.1-0.2 \mathrm{~mm}$ long, with a prominent nerve in the upper third of the pinnule and $2 \pm$ parallel minor nerves which do not reach the margin; apex broadly rounded or sometimes truncate, with a mucro less than $0.1 \mathrm{~mm}$ long; margin often dark red in the upper $1 / 3$ of the pinnule, the base slightly narrowed. Capitula of 12-20 flowers, borne in 7-15-branched racemes, arranged in terminal panicles or arising in the upper axils of the leaves, golden yellow, globose, 5-9 mm diam.; peduncle glabrous except minutely puberulous towards the apex, 3.5-5.0 mm long; bracts at the base of each peduncle, \pm oblong, hooded, dark brown, ciliolate along the margins; bracteoles composed of a claw $0.8-1.0 \mathrm{~mm}$ long and a peltate lamina $0.6-0.7 \mathrm{~mm}$ diam., both ciliolate with a fringe of white hairs. Flowers 5-merous; calyx 1.0 -1.3 mm long, paler towards the apex, dissected to $1 / 3-1 / 5$ of the length of the tube, glabrous or clothed with curled, hyaline hairs sometimes extending to the base of the tube; corolla $1.8-2.0 \mathrm{~mm}$ long, deeply dissected into glabrous, incurved, broadly rounded petals; stamens $3.0-5.3 \mathrm{~mm}$ long; ovary \pm oblong or elliptical-oblong, black, c. $0.6 \mathrm{~mm}$ long, c. $0.4 \mathrm{~mm}$ wide, clothed with few to many white hairs; style acentral or median. Legumes linear, $6.0-11.2 \mathrm{~cm}$ long, $0.7-1.0 \mathrm{~cm}$ wide, straight or falcate, glabrous, brown, dark blue or purplish brown, the surface finely but not prominently reticulate, very slightly constricted between the seeds, slightly convex over the seeds, the margin light brown, c. $0.5 \mathrm{~mm}$ wide. Seeds 6-12, longitudinal in the legume, oblong-ellipsoid to almost round, dorsiventrally flattened, 4-6 mm long, 3.0-3.5 mm wide, black, slightly glossy; pleurogram \pm prominent, Ushaped, widely open towards the hilum; areole black, raised, $3.5-4.5 \mathrm{~mm}$ long, $1.0-1.5$ $\mathrm{mm}$ wide; funicle light brown, filiform, broadening into a cupuliform aril beneath the seed (Figure 1). Flowering: September-early October. Fruiting: late December-February. The legumes probably take about 3-5 months to mature.

Distribution: $A$. blayana has a very restricted distribution occurring on the eastern side of the Great Dividing Range in Wadbilliga National Park on the South Coast of New South Wales, at approximately 200-600 m altitude (Boland \& Midgley 1983), in skeletal rocky soils, in steep mountainous country in almost pure stands or with Acacia mearnsii De Wild. It occurs in tall open-forests with Eucalyptus obliqua and other eucalypts and Tristaniopsis laurina. This species has also been recorded (L. Thomson 118, FRI, CBG, NSW) from Violet Hill, $21.8 \mathrm{~km} \mathrm{~N}$ of Bega, South Coast, N.S.W., on the Princes Highway, where it is growing adjacent to a Dept of Main Roads gravel dump and is likely to have been introduced. At Galoon Creek on the alluvial terraces $A$. blayana occurs with Acmena smithii, but on the steep exposed slopes above the creek it is a smaller tree $6-10 \mathrm{~m}$ high found in scrub with Eucalyptus wilcoxii on metamorphosed rocks in skeletal soil (P. Gilmour \& C. Helman, pers. comm.) (Figure 2).

Selected Specimens Examined: New South Wales: South Coast: Galoon Creek, Wadbilliga National Park, D.J. Boland 1888, 14.ii.1983 (CBG 8302001, NSW); c. $1 \mathrm{~km} \mathrm{E}$ of junction of Yankeys Creek and Brogo River, $36^{\circ} 29^{\prime}$ S, $149^{\circ} 37^{\prime}$ E, P. Cope CBG 8203158, 1.vii.1982 (CBG, NSW); N of Bemboka on the Nelsons Creek Trail, $36^{\circ} 29^{\prime}$ S, $149^{\circ} 40^{\prime}$ E, B.V. Gunn BG 621, 8.i.1985 (FRI, NSW); $15.6 \mathrm{~km}$ from Yankeys Gap along the Nelsons Creek fire trail, E.G. Cole 1474, 4.ii.1984 (CANB, NSW); $15.5 \mathrm{~km}$ along Nelsons Creek fire trail from junction with Yankeys Flat fire trail on $\mathrm{W}$ side of road, $36^{\circ} 29^{\prime} \mathrm{S}, 149^{\circ} 40^{\prime} \mathrm{E}, \mathrm{G}$. Butler 1368, 2.ii.1984 (CBG).

The specific epithet honours the conservationist John Blay, who made the original collections of this species. In 1981 he trekked through the rugged mountains west of Bermagui, N.S.W., for 9 months with his mule, Zac. Mr Blay's travels in this wilderness are described in his book (1987).

A. blayana belongs to a group of species in sect. Botrycephalae characterized by longer $(1.0-2.7 \mathrm{~cm})$ and wider $(2-5 \mathrm{~mm})$ pinnules than the majority of taxa in this section. 


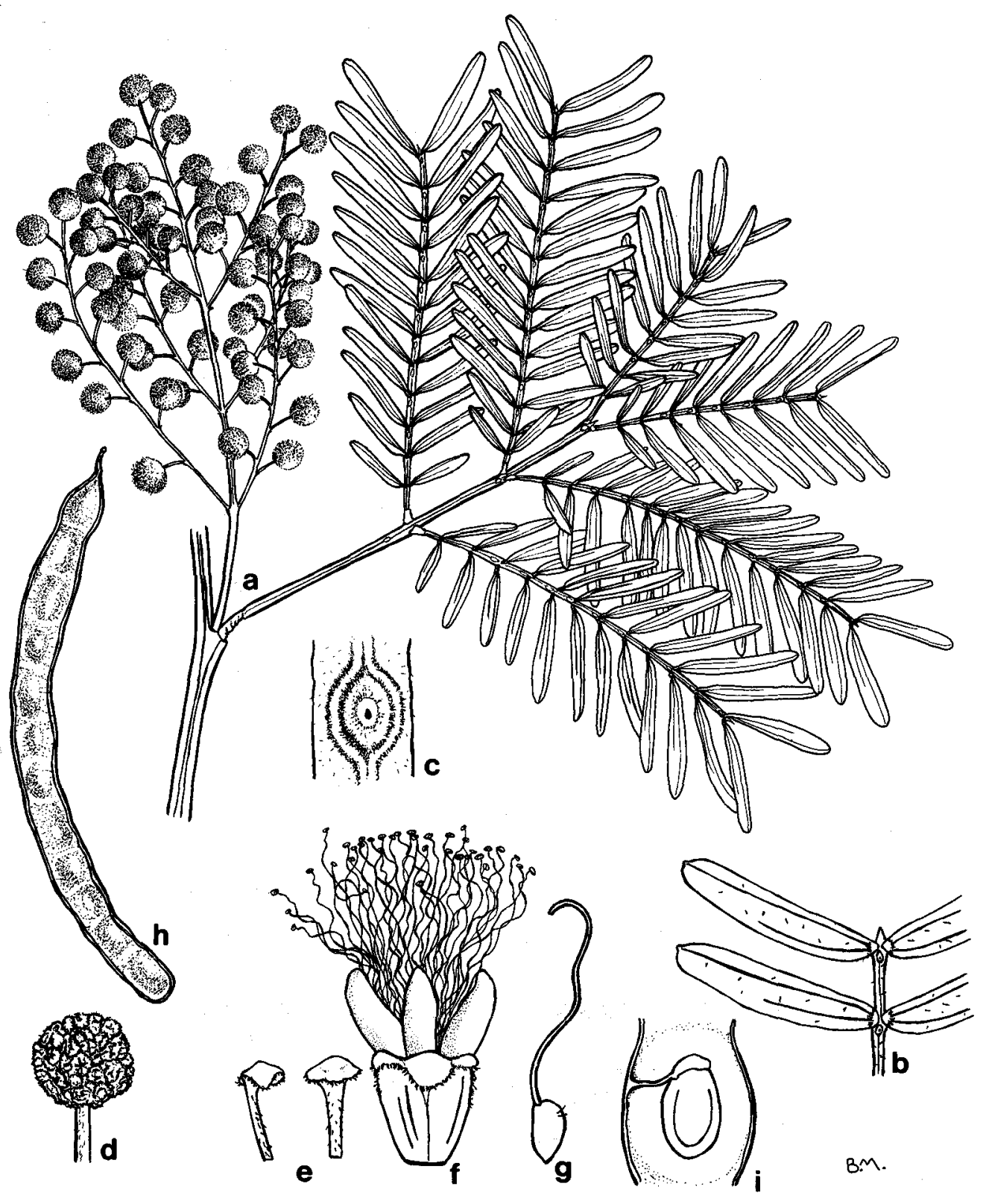

Figure 1. Acacia blayana. a. leaf and inflorescence $\left(x^{2 / 3}\right)$. b. apex of pinna with 2 pairs of pinnules $\left(x 1^{2 / 3}\right)$. c. gland of rhachis $(x 9)$. d. capitulum in bud $(x 4)$. e. 2 bracteoles $(x 131 / 3)$. f. flower $(x$ 13 1/3). g. ovary $\left(x 13\right.$ 1/3). h. legume $\left(x^{2 / 3}\right)$. i. seed $(x 3)$. Vouchers: a-g, I.R. Telford 10410; h-i, Lex Thomson 118. All figures drawn by B. Maloney. 


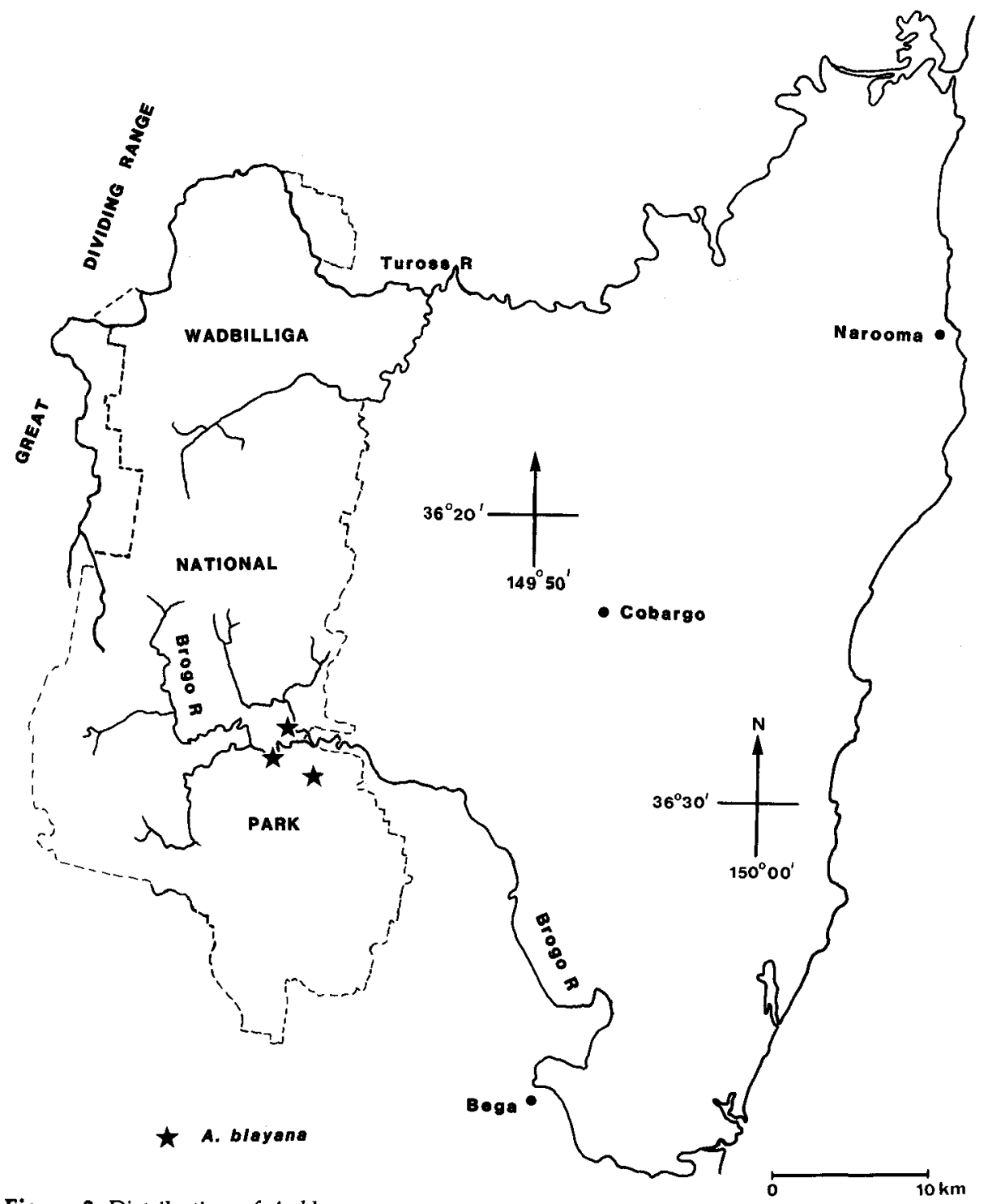

Figure 2. Distribution of A. blayana.

\section{Key to $A$. blayana and allied species}

1 Pinnules puberulous. Flowers golden, 12-20 in each capitulum. Ovary pubescent. [Rhachis with an orbicular gland at the base of each pair of pinnae, the gland below the lowest pair often slightly elongated and rarely up to $6 \mathrm{~mm}$ below the lowest pair. Tree to $25 \mathrm{~m}$ high]....

A. blayana

1* Pinnules glabrous. Flowers golden or pale yellow, 27-72 in each capitulum. Ovary glabrous

2 Capitula pale yellow, each composed of 27-49 flowers. Corolla c. $1.3 \mathrm{~mm}$ long. Calyx $0.5-1.0 \mathrm{~mm}$ long. Rhachis mostly with an orbicular gland only at the base of the uppermost pair of pinnae and with an orbicular petiolar gland usually at least $1 \mathrm{~cm}$ below the lowest pair of pinnae. Shrub or tree to 10 high. 
2* Capitula golden, each composed of 35-72 flowers. Corolla 2.0-2.4 mm long. Calyx $0.8-1.5 \mathrm{~mm}$ long. Rhachis with an orbicular or oblong gland at the base of the uppermost pair of pinnae only or sometimes also at the base of other pairs, the gland at the base of the lowest pair oblong. Shrub $1.0-2.5 \mathrm{~m}$ high or rarely a spindly tree to $5 \mathrm{~m}$ high

A. pruinosa

A. schinoides Benth. occurs on the lower North Coast and the Central Coast of New South Wales usually in sandstone gullies near creeks in tall open forest (Tindale 1972), whereas A. pruinosa Cunn. ex Benth. is found on the Darling Downs District of south-eastern Queensland (Pedley 1979), as well as on the Northern Tablelands and North Western Slopes of New South Wales often amongst granite boulders. The latter species frequently occurs in eucalypt-Callitris forest on infertile sandy soil.

Boland \& Midgley (1983) published a paper on A. blayana with notes on its distribution, ecology and wood as well as a short English description but did not validate the publication of this species with a Latin diagnosis or description.

\section{Acknowledgements}

We wish to acknowledge grants from the Australian Biological Resources Study in 1989 and from the Royal Botanic Gardens Research Fund in 1990 to Mary Tindale for the research assistance. We thank the Director and staff of the Australian National Botanic Gardens, Canberra, for the loan of specimens to NSW, as well as assistance in various ways, especially by Miss E.M. Canning and Messrs I.R. Telford and G.F. Butler. Grateful acknowledgment is made to Professor T.C. Chambers, Director, Royal Botanic Gardens, Sydney, for providing funds for the plate of $A$. blayana prepared by Mrs Betty Maloney. Our thanks are due to Mr John Blay who discovered this species and made special collections of it at various times. Messrs D.J. Boland, E.G. Cole, B.V. Gunn and S.J. Midgley (CSIRO Division of Forest Research), Mr P. Cope, and Dr R. Outhred assisted by collecting specimens and gathering data. The Royal Australian Air Force assisted substantially in the collection of specimens by providing helicopter transport to otherwise almost inaccessible country during exercises in the Wadbilliga area. We are indebted to Dr L.A.S. Johnson for checking the Latin diagnosis prepared by Mary Tindale, to Miss S. Armitage who prepared Figure 2, to Mr P. Kodela and Miss Armitage for the word-processing of this manuscript, and to $\mathrm{Mr} \mathrm{D}$. Martens for some assistance with the preparation of the map.

\section{References}

Blay, J. (1987) Trek through the Back Country (Methuen Australia: North Ryde).

Boland, D.J., \& S.J. Midgley (1983) Acacia 'blayana' A.B. Court - a new Australian tree with a future? Forest Genetic Resources Information No. 12: 21-23. (Food and Agriculture Organization of the United Nations).

Lee, A.T. (1948) The genus Swainsona. Contr. New South Wales Natl. Herb. 1: 131-271.

Pedley, L. (1979) A revision of Acacia Mill. in Queensland. Austrobaileya 1(3): 235-337.

Tindale, M.D. (1972) Group 8 (Bipinnate Acacias). Pp. 272-275 in N.C.W. Beadle, O.D. Evans \& R.C. Carolin, Flora of the Sydney Region, edn 2 (Reed Books: Frenchs Forest).

Manuscript received 3 November 1989 Manuscript accepted 1 May 1990 